\title{
Analisis Kandungan Klorofil Pada Anak Daun Tanaman Kelapa (Analysis of Chlorophyll Content in Children Leaves of Coconut Plants)
}

\author{
Muhammad Tawary ${ }^{1 *}$, Julius Pontoh ${ }^{1)}$, Lydia I.Momuat ${ }^{1)}$ \\ 1) Jurusan Kimia, FMIPA UNSRAT Manado \\ *Email korespondensi: rachmad.tawary@gmail.com
}

Diterima 7 Juli 2019, diterima untuk dipublikasi 10 Agustus 2019

\begin{abstract}
Abstrak
Tanaman kelapa banyak dibudidayakan sebagai tanaman pertanian. Tanaman kelapa memiliki nilai ekonomi yang tinggi karena hampir semua bagian tanaman kelapa memiliki manfaat ekonomis. Penelitian bertujuan untuk mengembangkan metode analisis klorofil pada daun dan menentukan bagian anak daun yang memiliki kandungan klorofil tertinggi. Analisis kandungan klorofil dilakukan dengan metode ektraksi pelarut yang absorbansinya dibaca pada spektrofotometer UV-Vis. Kandungan klorofil a dalam daun bervariasi pada setiap bagian anak daun tanaman kelapa. Kandungan klorofil a pada posisi tengah anak daun kelapa $\left(763.19 \mu \mathrm{mol} / \mathrm{m}^{2}\right)$ dan kandungan klorofil b (196.22 $\left.\mu \mathrm{mol} / \mathrm{m}^{2}\right)$. Kandungan klorofil a dan b pada setiap bagian anak daun dan posisi kanan dan kiri anak daun memiliki nilai yang relatif sama.

Kata kunci: Kelapa, klorofil a, klorofil b
\end{abstract}

\begin{abstract}
Many coconut plants are cultivated as agricultural crops. Coconut plants have high economic value because almost all parts of coconut plants have economic benefits. The study aims to develop a method of chlorophyll analysis on leaves and determine the part of leaflets which have the highest chlorophyll content. Analysis of chlorophyll content was carried out by a solvent extraction method in which the absorbance was read in a UV-Vis spectrophotometer. The content of chlorophyll a in leaves varies with each part of the leaves of the coconut plant. Chlorophyll a content in the middle position of coconut leaf child (763.19 $\mu \mathrm{mol} / \mathrm{m} 2)$ and chlorophyll b content (196.22 $\mu \mathrm{mol} / \mathrm{m} 2)$. The content of chlorophyll $a$ and $b$ in each part of the leaf child and the right and left positions of the leaves have relatively the same value.
\end{abstract}

Keywords: Coconut, Chlorophyll a, Chlorophyll b

\section{PENDAHULUAN}

Ketahanan pangan sangat ditentukan oleh produktivitas pertanian sedangkan produktivitas pertanian umumnya ditentukan oleh luas lahan dan jenis tanaman (Thirtle, et al. 2003). Tanaman kelapa banyak dibudidayakan sebagai tanaman pertanian.

Tanaman kelapa memiliki nilai ekonomi yang tinggi karena hampir semua bagian tanaman kelapa memiliki manfaat ekonomis. Daging buah kelapa dapat dikonsumsi secara langsung sebagai makanan segar atau dapat dijadikan bahan baku bagi pengolahan berbagai produk buah kelapa. Kelapa akan terus-menerus berperan penting dalam dunia perdagangan oleh karena itu produksi dan peroduktivitasnya harus ditingkatkan (Sukamto 2001). 


\begin{abstract}
Kelapa jenis genjah dapat menghasilkan 9.000-11.000 butir/ha/tahun setara dengan 1,5 - 2 ton kopra (Warisno 2003), atau setara dengan $3,375 \mathrm{Kg}$ bahan kering/ha/tahun.

Proses fotosintesis adalah penyusunan senyawa kimia yang kompleks dari karbon dioksida dan air. Sumber energi untuk proses fotosintesis adalah cahaya matahari. Proses ini dapat berlangsung karena adanya suatu pigmen yaitu klorofil (Arnon 1949).
\end{abstract}

Fungsi klorofil pada tanaman adalah menyerap energi dari sinar matahari untuk digunakan dalam proses fotosintetis yaitu suatu proses biokimia untuk mensintesis karbohidrat (gula menjadi pati), dari gas karbon dioksida dan air dengan bantuan sinar matahari (Lakitan 2007). Klorofil dapat dibedakan atas klorofil a dan b. Struktur molekul klorofil a mengandung gugus metil pada rantai sampingnya sedangkan klorofil b mengandung gugus aldehid (Campbell 2002).

Selain umur dan varietas daun, kandungan klorofil juga bervariasi dilihat dari posisi daun dalam satu tanaman. Analisis kandungan klorofil pada tanaman kelapa sawit menunjukkan bahwa selain umur daun, ternyata posisi daun yang berbeda pada umur daun yang sama, juga menunjukkan adanya variasi jumlah kandungan klorofil pada daun tersebut (Mustafa et al. 2015).

Posisi anak daun mengikuti posisi arah tegakan tangkai daun. Dengan demikian penangkapan cahaya matahari dapat maksimal. Posisi anak daun yang berbeda-beda pada satu tandan dan bagian anak daun aren yang panjang memungkinkan adanya perbedaan kandungan klorofil pada masing-masing bagian dan posisi anak daun (Mogea et al. 1991).

Tanaman palma seperti (kelapa, kelapa sawit, dan aren) memiliki struktur daun yang hampir sama membentuk susunan daun majemuk, bersirip genap, dan bertulang sejajar (Fauzi et al. 2004).

Telah dilakukan penelitian sebelumnya mengenai tanaman aren oleh Kamagi (2017), bahwa kandungan klorofil a yang terdapat pada daun aren bervariasi. Posisi anak daun pada daun memiliki kandunngan klorofil yang lebih tinggi pada bagian atas, sedangkan yang terendah pada bagian bawah. Daun aren pada posisi kiri mengandung klorofil lebih tinggi dari pada posisi kanan, sedangkan posisi pangkal, tengah, dan ujung pada anak daun hampir sama kandungan klorofilnya.

Pengukuran kadar klorofil secara spektrofotometri didasarkan pada hukum Lamber - Beer (Harbone 1987).

Hasil penelitian dari Porra (1989) dengan menggunakan berbagai macam pelarut di antaranya pelarut metanol menunjukkan absorbansi pada panjang gelombang $(\lambda)=665$ dan $652 \mathrm{~nm}$ dan menyimpulkan bahwa metanol sebagai ekstraktan klorofil yang baik.

Kandungan klorofil dalam komposisi daun dapat diklasifikasikan dalam berat per luas daun atau berat per berat daun. Hingga saat ini penelitian mengenai kandungan klorofil pada setiap bagian anak daun tanaman palma seperti (aren, kelapa, dan kelapa sawit) belum diteliti, untuk itulah penelitian ini dilakukan. Penelitian ini bertujuan untuk mengembangkan metode analisis klorofil pada daun dan menentukan posisi anak daun yang memiliki kandungan klorofil tertinggi.

\section{METODE \\ Alat dan bahan}

Alat yang digunakan dalam penelitian ini adalah alat-alat gelas, neraca analitik, alat sentrifugasi, lumpang dan alu, lemari pendingin, cool box, aluminium foil, gunting, one hole punch dengan diameter $4,2 \mathrm{~mm}$, alat pengukur panjang, dan spektrofotometer UV-Vis (Shimadzu 
UV-Vis 1800). Bahan yang digunakan dalam penelitian ini adalah sampel anak daun kelapa diambil di perkebunan Hamparan Mapalus, Kecamatan Minahasa Utara, Kelurahan Paniki, Provinsi Sulawesi Utara. Metanol PA (Merck), tissue, akuades, label, dan kantong plastik untuk menyimpan sampel.

\section{Preparasi Sampel}

Daun kelapa masing-masing diambil pada posisi atas dari tajuk tanaman. Sampel anak daun pada daun diambil pada posisi tengah selanjutnya dipisah menjadi tiga bagian, bawah, tengah, dan atas. Sampel diambil dari setiap bagian tersebut dengan cara dilubangi dengan menggunakan one hole punch. Berat setiap sampel diusahakan mencapai 0,1 gram atau setara dengan 18-24 lingkaran pada sampel daun kelapa tergantung masing-masing berat sampel tersebut. Selanjutnya sampel segera diberi label dan diletakkan dalam kantung plastik, kemudian sampel tersebut dimasukkan ke dalam lemari pendingin $\left( \pm 4-10^{\circ} \mathrm{C}\right)$.

Lingkaran yang dibentuk oleh one hole punch, dihitung luasnya dengan menggunakan rumus luas lingkaran, yaitu:

$$
\begin{gathered}
\text { Luas lingakaran }=\pi r^{2} \\
\text { dimana: } \pi=3,14 \\
r=\text { jari }- \text { jari lingkaran }
\end{gathered}
$$

\section{Ekstraksi sampel dan karakterisasi Absorbansi Klorofil (Porra et al., 1989)}

Sampel yang dianalisis diekstrak terlebih dahulu menggunakan metanol. Sebanyak 0,1 gram sampel dan $2 \mathrm{~mL}$ metanol dimasukkan ke dalam wadah lumpang, kemudian dihaluskan dengan cara digerus menggunakan alu. Lalu sampel yang telah digerus dimasukkan ke dalam gelas ukur. Setelah itu, lumpang dan alu yang telah digunakan untuk menghaluskan sampel, dibilas dengan $1,5 \mathrm{~mL}$ metanol sebanyak tiga kali. Tujuannya untuk melarutkan sisa-sisa sampel yang masih tertinggal.

Pelarut yang digunakan untuk membilas sisa-sisa sampel yang terdapat pada lumpang dan alu tersebut, dimasukkan bersama-sama dengan sampel yang telah dihaluskan dengan pelarut tadi ke dalam gelas ukur, dan ditambah metanol hingga mencapai volume 8 $\mathrm{mL}$. Ekstrak tersebut dimasukkan ke dalam tabung centrifuge dan disentrifugasi selama 25 menit dengan kecepatan 1000 rpm. Setelah didapatkan filtrat, maka filtrat diambil sebanyak $1 \mathrm{~mL}$ dan dilarutkan ke dalam $4 \mathrm{~mL}$ metanol dan dibaca absorbansinya dengan alat spektrofotometer UV-Vis (Shimadzu UV-Vis 1800) pada panjang gelombang 665 (Klorofil a) $\mathrm{nm}$ dan $652 \mathrm{~nm}$ (Klorofil b).

\section{Penentuan Konsentrasi Klorofil pada Daun}

Absorbansi yang telah dibaca pada panjang gelombang $665 \mathrm{~nm}$ dan $652 \mathrm{~nm}$ menggunakan pelarut methanol dimasukkan ke dalam rumus:

[Ch a] $=16,29 A_{665}-8,54 A_{652}$

[Ch b] $=30,66 A_{652}-13,58 A_{665}$

Dari rumus tersebut didapatkan konsentrasi klorofil yang ada pada daun aren, kelapa, dan kelapa sawit kemudian dihitung menggunakan persamaan luas area.

\section{HASIL DAN PEMBAHASAN Massa Sampel Daun Kelapa Per Keping Daun}

Setiap massa sampel per keping daun dari tiap bagian anak daun kelapa berbeda-beda. Pada posisi tengah anak daun kelapa memiliki massa berkisar antara 4.31 - 5.86 $\mathrm{mg} / \mathrm{keping}$ daun. Setiap bagian anak pada daun kelapa memiliki massa 
yang berbeda-beda karena memiliki ketebalan daun yang berbeda.

Massa sampel anak daun kelapa memiliki jumlah potongan yang berbeda-beda, 18-24 potongan pada sampel anak daun kelapa. Pada setiap bagian anak daun harus mencapai 0,1 gram. Tergantung berat dari setiap bagian anak daun.

Pada Gambar 1 dapat dilihat bahwa massa per keping daun posisi tengah pada setiap bagian anak daun kelapa memiliki massa yang berbeda-beda. Hal ini menunjukan bahwa setiap bagian anak daun pada daun memiliki ketebalan daun yang berbeda-beda.

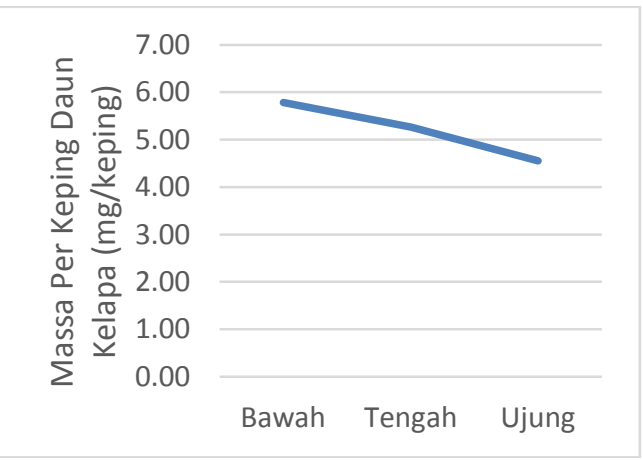

Gambar 1. Data massa sampel per keping daun pada ketiga bagian anak daun kelapa

\section{Panjang Gelombang Klorofil a dan Klorofil b}

Hasil scanning panjang gelombang daun kelapa (Gambar 2) memiliki pola yang sama dengan hasil scanning panjang gelombang klorofil a dan b yang telah dilakukan oleh Kamagi; 2017, namun diambil beberapa bagian saja untuk mewakili hasil scanning panjang gelombang pada daun aren. Hal ini membuktikan bahwa sampel yang diamati adalah sampel yang mengandung klorofil a dan klorofil $b$, karena klorofil a dan klorofil b terdapat pada tumbuhan tingkat tinggi seperti pada daun pohon kelapa, kelapa sawit, dan aren. Tumbuhan tingkat tinggi adalah tumbuhan yang memiliki batang, akar, dan daun sejati, seperti tumbuhan yang tergolong spermatophyta (tumbuhan berbiji) dan tanaman aren termasuk pada golongan spermatophyta (Danserau 1957).

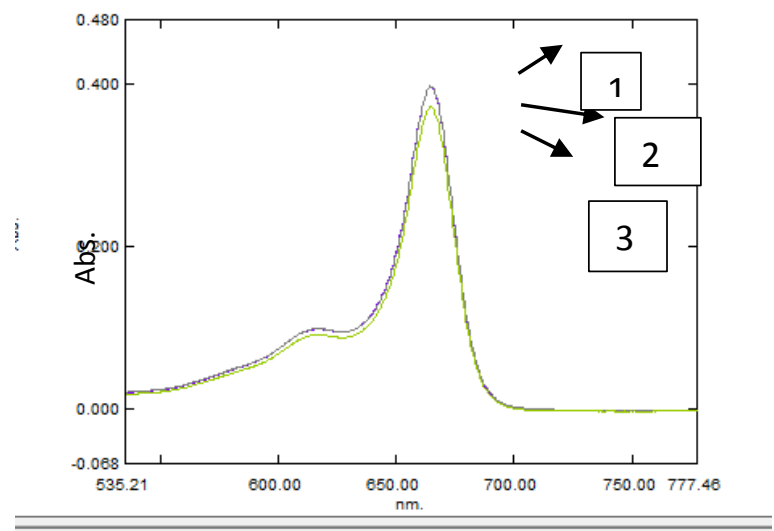

Gambar 2. Spektra hasil scanning dari ekstrak daun aren pada beberapa bagian dan posisi anak daun kelapa. (1. Anak daun kelapa bagian tengah dari posisi tengah daun bagian kanan, 2. Anak kelapa aren bagian bawah dari posisi tengah daun bagian kanan, 3.Anak daun kelapa bagian atas dari posisi bawah daun bagian kanan)

Hasil scanning pada gambar di atas juga membuktikan bahwa larutan ekstrak daun kelapa memiliki kandungan klorofil, karena hasil scanning pada larutan standar klorofil $a+b$ memperlihatkan pola yang sama dan antara bagian yang satu dengan yang lainnya juga memiliki pola yang sama pada peak nomor 13.

\section{Kandungan Klorofil a dan $b$ pada Daun Kelapa}

Satuan yang juga digunakan untuk menghitung kandungan klorofil a dalam penelitian ini adalah $\mu \mathrm{mol} / \mathrm{m}^{2}$. Konsentrasi klorofil a diubah ke $\mu \mathrm{mol}$, kemudian dibagi dengan luas daerah pada daun. Luas daerah sampel daun dihitung terlebih dahulu menggunakan rumus luas lingkaran karena sampel daun aren dipotongpotong menggunakan one hole 
punch sehingga membentuk lingkaran. Setelah didapatkan luas lingkaran maka penyebaran konsentrasi klorofil per satuan luas dapat dihitung dengan rumus. Hasil yang didapatkan dari perhitungan menggunakan satuan luas.

Spesies tanaman juga mempengaruhi banyaknya kandungan klorofil di mana setiap tanaman mempunyai jumlah klorofil yang berbeda-beda. dapat dilihat bahwa setiap jenis tanaman palma memiliki kandungan klorofil a yang berbeda-beda. Kandungan klorofil a pada daun aren lebih tinggi dibandingkan dengan data dari Kamagi (2017). Hal ini bisa jadi dipengaruhi pada saat preparasi sampel ataupun adanya kontaminasi.

Posisi tengah anak daun kelapa memiliki nilai kandungan klorofil sebesar $763.19 \mu \mathrm{mol} / \mathrm{m} 2$. Pada gambar 3 dapat dilihat bahwa nilai kandungan klorofil a berdasarkan luas area $\left(\mu \mathrm{mol} / \mathrm{m}^{2}\right)$ pada setiap bagian anak daun kelapa memiliki pola yang sedikit berbeda dengan data yang dilaporkan oleh Kamagi et al. (2017) tetapi memiliki nilai yang relatif hampir sama pada ketiga bagian anak daun

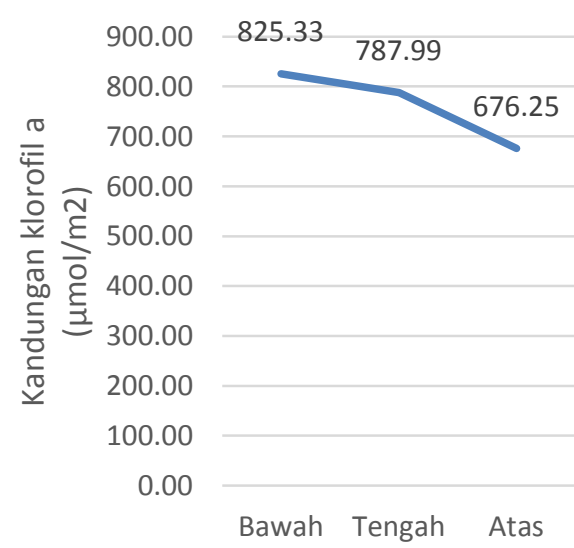

Gambar 3. Kandungan klorofil a pada bagian anak daun pada daun kelapa

Pada Gambar 4 dapat dilihat bahwa nilai kandungan klorofil a berdasarkan luas area $\left(\mu \mathrm{mol} / \mathrm{m}^{2}\right)$ pada posisi kanan dan kiri anak daun pada daun kelapa memiliki nilai yang relative hampir sama.

Pada Gambar 5 dapat dilihat bahwa nilai kandungan klorofil b berdasarkan luas area $\left(\mu \mathrm{mol} / \mathrm{m}^{2}\right)$ pada ketiga bagian anak daun memiliki pola yang sedikit berbeda dengan data yang dilaporkan oleh Kamagi et al. (2017) tetapi memiliki nilai yang relatif hampir sama pada ketiga bagian anak daun.

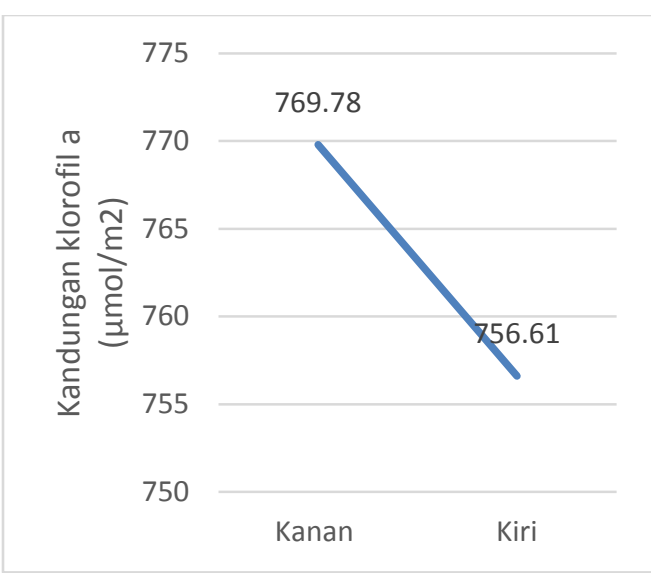

Gambar 4. Kandungan klorofil a pada posisi kanan dan kiri anak daun kelapa

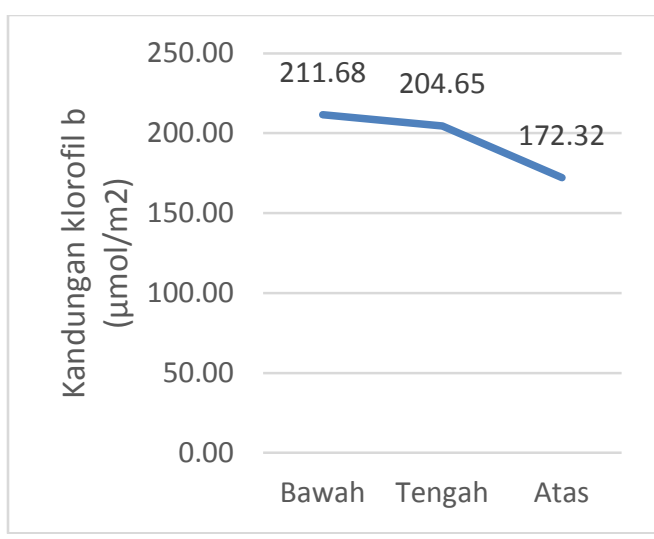

Gambar 5. Kandungan klorofil b pada setiap bagian anak daun

Pada Gambar 6 dapat dilihat bahwa nilai kandungan klorofil $b$ berdasarkan luas area $\left(\mu \mathrm{mol} / \mathrm{m}^{2}\right)$ pada posisi kanan dan kiri anak daun kelapa memiliki pola yang sama dengan data yang dilaporkan oleh 
Kamagi et al. (2017) dan memiliki nilai yang relatif sama antara posisi kanan dan posisi kiri anak daun.

Cahaya matahari merupakan salah satu faktor yang mempengaruhi kandungan klorofil di daun. Oleh sebab itu paparan cahaya matahari pada daun memiliki pengaruh. Posisi anak daun pada tandan daun kelapa, kelapa sawit dan aren yang panjang memiliki kemungkinan adanya perbedaan kandungan klorofil pada masing-masing anak daun karena foton yang diserap dari cahaya matahari tidak merata karena ada bagian anak daun yang berada di posisi yang lebih teduh.

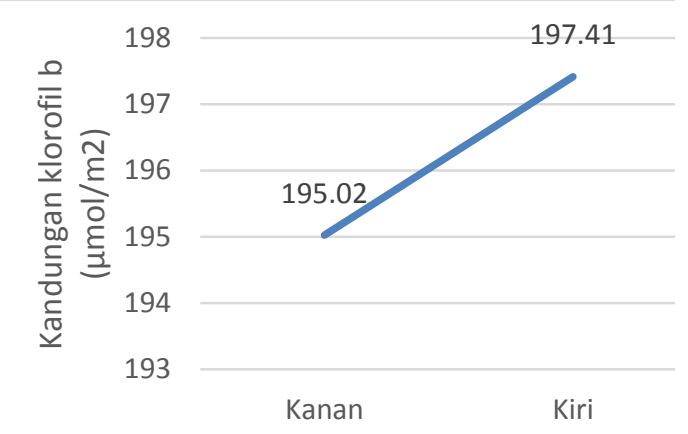

Gambar 6. Kandungan klorofil b pada posisi kanan dan kiri anak daun kelapa

Kebutuhan setiap tanaman terhadap paparan cahaya matahari berbeda-beda tergantung jenis tanaman dan varietasnya (Novita et al 2012). Terlihat bahwa posisi yang kemungkinan lebih banyak terpapar cahaya matahari memiliki kandungan klorofil yang lebih banyak dibandingkan dengan posisi yang teduh (Kamagi et al. 2017). Dalam penelitian ini untuk sampel daun kelapa menunjukan hasil yang berbeda di mana kandungan klorofil a lebih banyak terdapat pada posisi anak daun bagian bawah dan tengah yang kemungkinan lebih kecil terpapar cahaya matahari di bandingkan posisi anak daun bagian atas. Dari hasil yang berbeda yang di dapatkan kemungkinan terjadinya kesalahan saat preparasi sampel atau terjadinya penguapan ekstrak yang mengakibatkan terjadinya kenaikan konsentrasi pada saat sebelum disentrifugasi adapun juga disebabkan oleh pengaruh ketebalan daun pada berbagai jenis tanaman palma, posisis anak daun pada daun, bagian dari anak daun maupun posisi kanan dan kiri anak daun pada daun di mana ketebalan suatu daun juga berpengaruh terhadap banyaknya kandungan klorofil pada daun.

Menurut Salisbury dan Ross (1991), klorofil berasal dari proplastida yaitu plastida yang belum dewasa, kecil dan hampir tidak berwarna dan sedikit atau tanpa membran dalam. Proplastida membelah saat embrio berkembang, dan menjadi kloroplas ketika daun dan batang terbentuk. Pada organ yang terkena cahaya matahari, kloroplas muda akan aktif membelah sehingga dapat menghasilkan kloroplas-kloroplas baru yang mendukung terjadinya proses fotosintesis. Apabila intensitas cahaya yang diterima oleh tumbuhan hanya sedikit akan menyebabkan daun berwarna pucat. Hal ini berkaitan dengan data penelitian, bahwa posisi daun yang terpapar sinar matahari yang cukup memiliki kandungan klorofil yang lebih banyak dibandingkan dengan yang kurang mendapatkan sinar matahari.

Namun jika intensitas cahaya matahari terlalu tinggi, maka kandungan klorofil pada daun akan mengakibatkan kerusakan klorofil. Suhu yang tinggi akibat intensitas penyinaran yang tinggi dapat mengakibatkan degradasi klorofil dan memberi pengaruh terhadap aktivitas enzim klorofilase dan enzim lipoksidase (Oktaviani 1987).

\section{KESIMPULAN}

Kandungan klorofil a pada posisi tengah anak daun kelapa (763.19 $\mu \mathrm{mol} / \mathrm{m}^{2}$ ) dan kandungan klorofil $\mathrm{b}$ (196.22 $\left.\mu \mathrm{mol} / \mathrm{m}^{2}\right)$. Kandungan klorofil 
a dan b pada setiap bagian anak daun dan posisi kanan dan kiri anak daun memiliki nilai yang relatif sama.

\section{DAFTAR PUSTAKA}

Arnon DI (1949) Copper enzymes in isolated chloroplasts polyphenoloxidase in beta vulgaris. Plant Physiology. 24: 1 15.

Campbell (2002) Biologi Edisi Kelima Jilid Erlangga. Jakarta.

Dalibard C (1999) Overall view on the tradition of tapping palm trees and prospects for animal production. Livestock Research for Rural Development, 11: 1 .

Dansereau P (1957) Biogeography an ecological perspektive. The Ronald Press. New York.

Fauzi YEW, Yustina S, Iman $\mathrm{H}$ dan Rudi (2004) Budidaya, pemanfaatan hasil dan limbah dan analisis usaha dan pemasaran kelapa sawit. Penerbit Swadaya. Jakarta.

Harborne JB (1987) Metode fitokimia. Penerbit ITB Bandung.

Kamagi L, Pontoh J, dan Momuat LI (2017) Analisis kandungan klorofil pada beberapa posisi anak daun aren (Arenga pinnata) dengan spektrofotometer UV-Vis. Jurnal FMIPA UNSRAT. 6(2): 4954.

Lakitan B (2007) Dasar-dasar fisiologi tumbuhan. PT. Raja Grafindo Persada Jakarta.

Mogea JB, Siebert, and Smits W (1991) Multipurpose palms: the sugar palm (Arenga pinnata (Wurmb) Merr. Agroforestry System. 13: 111-129.

Mustafa N, N Ya'acob, ZA Latif, and AL Yusof (2015) Quantification of oil palm tree leaf pigment (Chlorophyll A) concetration based on their age. Jurnal Teknologi. $75: 129-134$.

Novita N, N Soverda, dan Gusniwati (2012) Pengaruh naungan terhadap kandungan klorofil daun dan hasil dua varietas tanaman kedelai (Glycine max $L$. merill) (The effect of shade on chlorophyll content and the yield of two soybean varietes (Glycine max L. merill). Jurnal Program Studi Agroteknologi. 3: 188-196.

Oktaviani L (1987) Perubahanperubahan yang terjadi pada ekstrak warna hijau daun suji (Pleomele angustifolia) selama penyimpanan [skripsi]. Bogor: Fakultas Teknologi Pertanian, Institut Pertanian Bogor.

Porra RJ, WA Thompson, and PE Kricdeman (1989) Determination of accurate extinction coefficients and simultaneous equations for assaying chlorophylls $a$ and $b$ extracted with four different solvents: verification of the concentration of chlorophyll standads by atomic absorption spectroscopy. Biochimia et Biophysica Acta. 975: 384-34.

Salisbury FB dan Ross CW (1991) Fisiologi tumbuhan jilid 1. Terjemahan oleh Dr. Diah R. Lukman dan Ir. Sumaryono, MSc. 1995. Bandung: Penerbit ITB.

Sukamto (2001) Upaya meningkatkan produksi kelapa, PT. Penebar Swadaya, Jakarta.

Thirtle C, Lin Lin J and Piesse (2003) The impact of research-led agricultural productivity growth on poverty reduction in africa, asia and latin america. World Development 31(12): 1959-1975.

Warisno (2003) Budidaya kelapa genjah. Kanisius, Yogyakarta. 